\title{
Classified US technology for transfer to Japan
}

\section{Tokyo}

JAPAN and the United States last week signed an agreement that will allow transfer of information on classified US military technology to Japan. The agreement is one of several in a series designed to promote joint military research. But critics say that these moves, which mark a major shift in Japanese policy, are being made without public debate.

Under the new accord, signed by Foreign Minister Sosuke Uno and Mike Mansfield, the US Ambassador to Japan, Japan can gain access to classified US patents provided the information is used for defence purposes only and is kept strictly secret. Classified US inventions can be patented in Japan without public disclosure, and Japanese patents resulting from joint military research can also be classified. Furthermore, Japanese patent applications for technology that would expose classified patented technology will not be publicly disclosed unless it can be

\section{Who goes there?}

\section{Tokyo}

ThE narrow channels linking the Japan Sea to the Pacific Ocean are rumoured to be bristling with sophisticated listening equipment for detecting passing Soviet submarines. But one seldom hears about it - except, that is, when unsuspecting oceanographers encroach upon the area.

A joint team of researchers from Hokkaido University's Laboratory of Ocean Bottom Seismology and West Germany's Hamburg University are planning to carry out a seismic survey off the coast of Okinawa from Tuesday this week (19 April) by letting off powerful depth charges (up to $200 \mathrm{~kg}$ ) at $130-150 \mathrm{~m}$ below the sea surface. The reflected seismic waves from the explosions will be picked up by ocean-bottom and landbased seismometers and will provide information on the structure of the Earth's crust and mantle down to $30-50 \mathrm{~km}$ in an area where the Philippine plate plunges beneath Japan.

But Japan's Defence Agency objected to the survey and asked the researchers drastically to modify their plans because the agency feared the 'artificial earthquakes' would affect their 'oceanographic equipment' installed on the seafloor.

After last-minute mediations by the Foreign Ministry, it has been agreed that the project can go ahead, provided the researchers give the agency warning of the timing and location of all explosions at least one day in advance.

David Swinbanks established that the invention was made independently.

The agreement became effective immediately and does not require Diet approval because it invokes 'sleeping' provisions of a US-Japan agreement on interchange of patent rights and technical information for defence purposes which was approved by the Diet in 1956.

The agreement will smooth the way for Japan's participation in the US Strategic Defense Initiative (SDI), which Japan joined last year and will allow joint USJapan development of other military technology.

Japan already produces military weapons under licence from US defence contractors but the technology is provided in the form of 'black boxes', the technology secrets of which are not disclosed to the manufacturers.

The new agreement is one of a series involving military research. Following the uproar last year over Toshiba Machine's illegal export of propeller-milling machines to the Soviet Union, Japan's Defence Agency and the US Pentagon agreed to increase cooperation in antisubmarine warfare research (see below).

And the new US-Japan Science and Technology Agreement, which is expected to be finalized in the next few months,

includes provisions to safeguard secret military research and prevent transfer of military technology or information to third countries.

In a recent television programme, Dr Koji Fushimi, former president of the Science Council of Japan and a member of the upper house of the Diet, expressed grave concern over Japan's increased commitment to joint military research with the United States. Japan spends only 0.01 per cent of gross national product on defence research, very much less than the United States, 0.7 per cent. Japanese researchers value their open research system and many economists argue that Japan's concentration on civilian research and development has helped the conquest of consumer markets.

But Fushimi fears that Japan's researchers will show weak resistance to the encroachment of secret military research. He says they should debate the issue more but there is a complete lack of information from the government on the new accords. Fushimi is particularly concerned about the new US-Japan Science and Technology Agreement.

When the original agreement was made in 1980 it was intended to promote joint research for 'peaceful' purposes. But the new agreement will be expanded to include military research, and problems over maintaining the secrecy of such research in Japan has been one of the major stumbling blocks in negotiations.

David Swinbanks

\section{UK relents on European space decision}

\section{London}

THE British government announced this week that it will apply to participate in the Columbus programme of the European Space Agency (ESA), one of the 'Big Three' projects approved by ministers last November but which Britain had refused to support.

Britain now proposes to contribute $£ 250$ million to the $£ 2,800$-million, ten-year project in preference to taking part in the Canadian-led Radarsat venture, which would have cost Britain around $£ 100$ million and which will be four years in advance of Columbus.

Britain's interest in Columbus, which will form part of the international space station, lies principally in the polar platform, a remote-sensing satellite. When ministers agreed to the Columbus proposals (see Nature 330,$195 ; 1987$ ) the projected cost of the polar platform was around $£ 500$ million. Pressure from Britain's space minister, Kenneth Clarke, resulted in a scaling-down of the specifications. The platform will not now be manserviced and its weight will be reduced from 3.5 to 2 tonnes. The revised cost is some $£ 315$ million.
Britain is hoping that the bulk of the work on the polar platform will be awarded to British Aerospace. To allow Britain's involvement in Columbus, the government has allocated an extra $£ 20$ million to the British National Space Centre over the next three years, on top of its annual budget of $£ 116$ million. Clarke has also persuaded industry to provide $£ 5$ million to help offset the cost of participation.

A new director-general of the space centre was also announced last week. $\mathrm{He}$ is Mr Arthur Pryor, a civil servant from within the Department of Trade and Industry, the space centre's parent body. The centre has been without a director-general since the retirement in February of Mr Jack Leeming, who took over last September following the politically embarrassing resignation of Mr Roy Gibson in a gesture of exasperation at the government's refusal to meet an urgent request for more cash. Like Leeming, Pryor will be at Grade 3 on the civil service scale - a grade lower than Gibson when he occupied the directorgeneral's chair. The change in the directorgeneral's status is seen as an indication of the present administration's attitude towards space.
Simon Hadlington 